\title{
Viral and Toxoplasma gondii infections in children after liver transplantation
}

\author{
A Salt, G Sutehall, M Sargaison, C Woodward, N D Barnes, R Y Calne, T G Wreghitt
}

\begin{abstract}
The incidence and morbidity of viral and Toxoplasma gondii infections were studied in 40 children who underwent liver transplantation between December 1983 and February 1988. The incidence of primary and reactivated cytomegalovirus (CMV) infection was $19 \%$ and $47 \%$, respectively; primary infection caused clinical disease in all five cases affected and was fatal in one. Primary EpsteinBarr virus (EBV) infection occurred in 10 $(26 \%)$ recipients but caused only mild disease. No reactivated EBV infection was recorded and no lymphoproliferative disorders associated with EBV were found after a maximum of four years' follow up. Adenovirus infection occurred in seven $(18 \%)$ patients; this was associated in one case with fatal pneumonia and fulminant hepatitis, but otherwise with only mild respiratory disease. Primary $T$ gondii infection was detected in one patient who remained asymptomatic. Other viruses causing infection included herpes simplex, varicella zoster, and respiratory syncytial virus.
\end{abstract}

Surveillance for these infections and the long term sequelae should be included in the follow up of all children who undergo transplantation.

Public Health

Laboratory,

Addenbrooke's

Hospital, Cambridge

Department of

Paediatrics

A Salt

N D Barnes

Department of

Surgery

R Y Calne

Department of

Pathology

M Sargaison

Department of

Clinical Microbiology

T G Wreghitt

Public Health

Laboratory, Leeds

CWoodward

Correspondence to:

Dr T G Wreghitt, Clinical

Microbiology and Public

Mealth Laboratory,

Addenbrooke's Hospital,

Cambridge, England.

Accepted for publication

31 August 1989
Viral infections are a major cause of morbidity and mortality after organ transplantation, when cytomegalovirus (CMV), Epstein-Barr virus (EBV), and adenovirus infections are particularly common. ${ }^{12} \mathrm{CMV}$ has been studied extensively, and its potential for transfer with the donor organ ${ }^{3}$ and for reactivation with immunosuppression ${ }^{4}$ is well recognised in renal, ${ }^{5}$ bone marrow, heart ${ }^{67}$ and liver transplant recipients. ${ }^{8} \mathrm{EBV}$ and adenovirus, although not transmitted with the donor organ, have similar potential and may cause serious disease after organ transplantation. ${ }^{9}$ There is also increasing evidence associating EBV infection with the subsequent development of lymphoproliferative disorders. ${ }^{1011}$ Toxoplasma gondii can also be transmitted with the donor organ, and fatal disseminated disease has been reported after heart, renal, and liver transplantation in adults. ${ }^{12-14}$

The impact of these infections in children after liver transplantation has not been well documented, but the Pittsburgh group have recently reported their experience..$^{15}$ The
Cambridge/King's College Hospital liver transplantation programme now includes more than 70 children under 16 years. Here we review our experience with CMV, EBV, adenovirus, other viral infections and $T$ gondii, and compare our findings with those in our adult liver transplant recipients and with those of the children reported from Pittsburgh.

\section{Patients and methods}

Between December 1983 and February 1988, 63 children received liver transplants. There were sufficient serum samples available for analysis from 40 (14 boys and 26 girls) who survived for four weeks or more after transplantation. At the time of transplantation their ages ranged from seven months to 17 years with a mean age of 6.7 years. Seventeen children were aged 3 years or less. Twenty eight of 40 patients had biliary atresia/hypoplasia, the remainder had a variety of conditions, including $\alpha$-1-antitrypsin deficiency and other metabolic disorders. Five children received a second transplant during this period. For two, who underwent a further transplantation within two weeks of the first, only the second postoperative period was included.

In all children intravenous cyclosporine was started 48 to 72 hours after transplantation, in a dose of $2 \mathrm{mg} / \mathrm{kg} /$ day increasing to $4 \mathrm{mg} / \mathrm{kg} /$ day . This was changed to oral cyclosporine, $10 \mathrm{mg} /$ $\mathrm{kg} / \mathrm{day}$, in the second week when the T-tube was clamped. Methylprednisolone, $10 \mathrm{mg} / \mathrm{kg}$, was given intraoperatively and prednisolone ( $2 \mathrm{mg} / \mathrm{kg} /$ day initially, reducing to $1 \mathrm{mg} / \mathrm{kg} /$ day by two weeks), and azathioprine $(1.5 \mathrm{mg} /$ $\mathrm{kg} /$ day) were started immediately after the operation. Episodes of acute rejection were treated with intravenous methylprednisolone, $1.0 \mathrm{~g} / 1.76 \mathrm{~m}^{2} /$ day for three days. Immunosuppression was reduced or temporarily withdrawn during episodes of severe infection.

Samples for serological analysis were taken before transplantation, then weekly throughout the hospital admission, and on subsequent follow up visits. Serum samples were also available from 25 donors.

Serological tests were performed to detect antibodies to CMV, EBV, adenovirus, herpes simplex virus (HSV), varicella zoster virus (VZV) and $T$ gondii.

The complement fixation test (CFT) was performed as described by Bradstreet and Taylor, ${ }^{16}$ with three $50 \%$ haemolytic doses of guinea pig complement to detect antibody to CMV, HSV, VZV and adenovirus. Sera before 
and after transplantation from each patient were titrated in parallel.

To detect CMV antibody in those sera with a CMV complement fixation titre of less than 8 , and in certain others which showed anomalous CMV complement fixation titres, the more sensitive competitive enzyme linked immunosorbent assay (ELISA), as described by Wreghitt et al, ${ }^{17}$ was performed. Serum samples from patients who showed a $\geqslant$ four-fold rise in CMV complement fixation titre, or who seroconverted, were tested for CMV specific IgM by means of a $\mu$ capture ELISA. ${ }^{18}$

Serum samples before and after transplantation were titrated for EBV anti-viral capsid antigen IgG by the indirect immunofluorescence method of Henle and Henle ${ }^{19}$ with the HRI-K subline of the P3J line of Burkitt's lymphoma cells. ${ }^{20}$ Serum samples were also tested for EBV nuclear antigen (EBNA) antibody in an anti-complement immunofluorescence test ${ }^{21}$ and anti-EBV early antigen (EA) antibody in an immunofluorescence test ${ }^{22}$ using P3HR-1 virus superinfection. ${ }^{23}$

Antibodies to $T$ gondii were assayed in the latex agglutination test (Toxoreagent, Eiken Chemical Company of Japan), as described by Balfour et al. ${ }^{24}$

Some sera were also tested for the presence of antibodies to $T$ gondii by the dye test and the indirect haemagglutination test. $T$ gondii specific IgM was detected by ELISA, as described by Payne et al. ${ }^{25}$

Throat swabs, nasopharyngeal aspirates, and urine samples were obtained for viral culture when clinically indicated.

\section{INFECTION}

Primary infection was defined as seroconversion from initially undetectable to detectable antibody titres to a specific viral antigen. This diagnosis was supported where appropriate by detection of specific IgM, and in many cases, by virus isolation.

Reactivated infection was diagnosed by a four-fold (16-fold in the case of EBV) or greater rise in antibody titre.

The clinical course of all patients was reviewed to correlate clinical symptoms and signs of infection with the laboratory data. Symptomatic viral infection was defined as a continuous or intermittent fever of $>38^{\circ} \mathrm{C}$ for at least seven days, with no evidence of other microbial infections or rejection episodes, in association with other clinical and laboratory evidence of viral infection.

\section{Results}

Twenty seven children had serological evidence of viral infection, with a total of 34 infective episodes. Six children had more than one viral infection (table 1).

CYTOMEGALOVIRUS (CMV)

Of the 29 seronegative recipients, five (19\%) developed primary CMV infection; all five developed CMV specific IgM ( $\geqslant 10$ units). CMV was isolated from urine culture in three patients.
Table 1 Patients with multiple infections

\begin{tabular}{llllll}
\hline Case No & CMV & EBV & Adenovirus & HSV & VZV \\
\hline 3 & - & + & + & - & - \\
5 & + & + & - & - & - \\
6 & - & + & + & + & - \\
14 & - & + & + & - & - \\
24 & + & - & - & + & - \\
31 & + & - & - & - & + \\
\hline
\end{tabular}

The donor CMV antibody status was not known for all cases, particularly those who received a transplant before 1986 . Since then the importance of the donor organ in transmission of CMV has been recognised. Three of the five children who developed primary CMV infection received organs from CMV positive donors. The donor CMV antibody status was not known for the other two. Only one child who was CMV antibody negative, and was known to have received a CMV positive organ failed to acquire primary infection.

All children with primary CMV infection had clinically important disease. The main clinical features of the infection are summarised in table 2. The three patients who developed infection within one month of liver transplantation had severe disease. One child died with pneumonitis and encephalitis 47 days after transplantation. Another, who had received methylprednisolone for an episode of acute rejection, subsequently developed CMV hepatitis; liver function was abnormal for six months but has remained normal since. The third child developed moderately severe pneumonitis and duodenal ulceration. Each of these children was treated with Cymevene (ganciclovir) soon after the onset of symptoms.

Reactivated CMV infection arose in eight $(47 \%)$ of the 17 children who were seropositive before transplantation. In six this occurred within four weeks of transplantation during the time of maximal immunosuppression, in one at eight weeks, and in the last at seven months during a terminal episode of septicaemia. Only two children were symptomatic. The symptoms were mild and included fever of one to three weeks' duration, anorexia and diarrhoea, coinciding with the rise in CMV complement fixation antibody titre, development of CMV specific $\operatorname{IgM}$ ( $<10$ units), and isolation of CMV from the urine.

EPSTEIN-BARR VIRUS (EBV)

Of the 39 children from whom serum was available, 22 were seronegative before transplantation. Of these, 12 showed $a \geqslant 16$-fold rise in antibody to EBV viral capsid antigen. In two patients who showed a minimum 16-fold rise in

Table 2 Primary CMV infection: clinical features

\begin{tabular}{lcccccc}
\hline & \multicolumn{3}{c}{ Case $N o$} & & & \\
Symptoms & 5 & 16 & 22 & 25 & 27 \\
\hline Onset (days after transplantation) & 52 & 76 & 23 & 28 & 26 \\
Fever $\left(>38^{\circ} \mathrm{C}\right.$ ) (No of days) & 7 & 21 & 21 & 35 & 32 \\
Hepatitis & - & + & - & - & + \\
Pneumonitis & - & - & + & + & - \\
Gastrointestinal haemorrhage & - & - & + & + & - \\
Central nervous system & + & - & - & + & - \\
Leucopenia & + & - & + & - & - \\
Thrombocytopenia & + & - & - & - & - \\
Death & - & - & - & + & - \\
\hline
\end{tabular}


VCA IgG antibody, however, this could not be confirmed in tests for viral capsid antigen $\operatorname{IgM}$, EBNA, and EA tests. Ten (45\%) children, therefore, had confirmed primary infection. Their average age was 2.9 years (range $0-11$ years) and eight (73\%) were under 3 years.

Six children had symptoms which coincided with seroconversion. The most common feature was prolonged fever of two to eight weeks' duration, with mild, non-specific constitutional upset. Concurrent mild deterioration in liver function was noted in most cases. None of the children displayed the typical features of a mononucleosis syndrome with pharyngitis and lymphadenopathy, and no atypical lymphocytes were found. Infection was noted between three weeks and 13 months after transplantation. Serological evidence of EBV infection was found in three cases simultaneously or within a few weeks of changes in CMV and adenovirus antibody titres, which increased the difficulty of ascribing symptoms specifically to EBV infection.

Reactivated EBV infection was not found in any of the 17 children who had antibodies to EBV before transplantation. Follow up of these patients (to September 1989) has shown no evidence of lymphoproliferative disorders. The longest period of follow up for patients with EBV infection in this series was four years and the shortest nine months.

\section{ADENOVIRUS}

Adenovirus infection was diagnosed on the basis of $a \geqslant$ four-fold rise in adenovirus complement fixation antibody titre together with culture when available. Eight $(19 \%)$ children showed evidence of infection; three had serological evidence of previous infection. Infection arose late postoperatively, between three and 12 months in all but two patients. Adenovirus was isolated and typed in only two cases because most patients were no longer in hospital at the time of infection.

One child, from whom adenovirus type 7 was isolated from a nasopharyngeal aspirate taken on the fourth day after surgery, was retransplanted on day 14 . She subsequently developed a high fever and interstitial pneumonia and died of respiratory failure nine days after her second transplantation. Adenovirus type 7 was isolated from lung, liver, spleen and kidney at necropsy.

Four other children had symptoms associated with adenovirus infection. All had fever of about one week's duration, coryza, pharyngitis and conjunctivitis. One child also had a prominent mobilliform rash.

\section{HERPES SIMPLEX VIRUS}

There were no primary infections with HSV in this series, but three of the 10 children who were seropositive preoperatively had subsequent reactivated $\mathrm{HSV}$ infection. Mucosal ulceration was present in all cases. Two of these had associated fever in the early period after surgery at four and eight weeks, respectively, and were treated with intravenous Zovirax (acyclovir). A significant ( $\geqslant$ four-fold) rise in HSV antibody titre was shown in all cases and
Table $3 T$ gondii antibody titres in one patient with primary infection

\begin{tabular}{lllll}
\hline & \multicolumn{4}{l}{ Antibody titres } \\
\cline { 2 - 5 } Transplantation & LA test & Dye test & HA test & IgM \\
\hline Before & $<8$ & $<8$ & $<32$ & - \\
After (day 21) & 2048 & 8000 & 1024 & 198 units \\
\hline
\end{tabular}

LA = Latex agglutination

HA = Haemagglutination

HSV was isolated in two. In a fourth child HSV was isolated without a noticeable change in antibody titre or symptoms.

\section{VARICELLA ZOSTER VIRUS}

One child developed chicken pox after contact with a brother with the disease. She had two brief grand mal convulsions, but no VZV antibody was found in the cerebrospinal fluid. The immunosuppression was interrupted; she was treated with zoster hyperimmune globulin and acyclovir and recovered without sequelae.

\section{RESPIRATORY SYNCYTIAL VIRUS}

Respiratory syncytial virus infection was found in one child who developed moderately severe bronchiolitis eight weeks after transplantation, 10 days after recovering from EBV infection.

\section{T GONDII INFECTION}

$T$ gondii infection was diagnosed serologically in only one patient who showed $a \geqslant$ four-fold rise in latex agglutination $T$ gondii antibody titre (table 3 ). This child, who was $T$ gondii antibody negative before transplantation, received an organ from an antibody positive donor. The rise in titre occurred three weeks later, one week after the withdrawal of immunosuppressive treatment because of a left hepatic lobe abscess. This was after treatment for acute rejection with methylprednisolone. Treatment with pyrimethamine was given for six weeks. There were, however, no clinical symptoms or signs which could be ascribed to this infection.

\section{Discussion}

The aim of this study was to assess the impact of viral and $T$ gondii infections on our paediatric liver transplant recipients and to describe some of the patterns of clinical disease associated with these infections. Our findings will be compared with those of other series, in particular, those of Breinig et al. ${ }^{15}$

CMV is the most common viral cause of morbidity in immunosuppressed patients, including all organ transplant recipients. A high incidence of CMV infection has been reported in adult series for kidney $(50-96 \%),{ }^{34}$ liver $(50-77 \%),{ }^{826}$ and heart $(48 \%)^{12}$ transplantation. In our study CMV was responsible for most of the severe morbidity experienced and for one of the two fatal viral infections.

Thirty per cent of our study group developed $\mathrm{CMV}$ infection, and primary infection was seen in $19 \%$ (five of 26 ) of CMV antibody negative children. This is comparable with the findings of Breinig $e$ al $^{15}$ and also with those of our adult liver transplant series (table 4). Reactivated CMV infection was found in eight of $17(47 \%)$ 
Table 4 CMV infection: comparison between Cambridge and Pittsburgh liver transplant recipients

\begin{tabular}{|c|c|c|c|}
\hline & \multicolumn{2}{|l|}{ Children } & \multirow{2}{*}{$\frac{\text { Adults }}{\text { Cambridge }}$} \\
\hline & Cambridge & Pittsburgh & \\
\hline Total No of patients & 43 & 43 & 32 \\
\hline $\begin{array}{l}\text { Total No (\%) } \\
\text { with CMV infection }\end{array}$ & $13(30)$ & $13(30)$ & $15(50)$ \\
\hline $\begin{array}{l}\text { Total No }(\%) \\
\text { seronegative }\end{array}$ & $26(60)$ & $35(81)$ & $12(38)$ \\
\hline $\begin{array}{l}\text { No }(\%) \text { seronegative } \\
\text { with CMV infection }\end{array}$ & $5(19)$ & $6(17)$ & $3(25)$ \\
\hline $\begin{array}{l}\text { Total No (\%) } \\
\text { seropositive }\end{array}$ & $17(40)$ & $8(19)$ & $20(62)$ \\
\hline $\begin{array}{l}\text { No (\%) seropositive } \\
\text { with CMV infection }\end{array}$ & $8(47)$ & $7(88)$ & $12(60)$ \\
\hline
\end{tabular}

of our antibody positive recipients, which is comparable with the findings in our adult group (table 4). Children who had primary CMV infection experienced the most serious disease, with one fatality. Only mild symptoms were experienced by the two symptomatic patients who had reactivated infection.

In contrast, the Pittsburgh group found that primary CMV infection occurred less frequently in their paediatric recipients than in adults. They also found a significantly higher incidence of reactivated CMV infection in both children and adults.

The incidence of CMV antibody increases with age from $5-20 \%$ at 12 months, ${ }^{2728}$ to $40 \%$ at 20 years, and $70-80 \%$ by 60 years. ${ }^{29}$ The likelihood of a child receiving an organ from a CMV seropositive donor is therefore less than that for an adult. This may change in the future with the increasing use in children of liver reduction operations using older donors: we do not have complete serological data for all donors in this series. The proportion of positive donors, however, was $26 \%$ (five of 19 ) of those tested and that of recipients $40 \%$ (17 of 43 ). There is therefore a considerable risk of CMV antibody negative children receiving organs from CMV antibody positive donors and hence of serious donor acquired CMV disease in children. Every effort should be made to screen donors for CMV antibody and to avoid CMV mismatch. This has proved difficult in the past because of the scarcity of child donors and the urgency of transplantation. The recent availability of the CMV scan latex agglutination test, however, (Becton-Dickinson), which is reliable, rapid, and simple to perform, has meant that antibody testing can easily be done before donors and recipients are matched. ${ }^{30}$

EBV infection has been increasingly recognised as a cause of morbidity after organ transplantation and also of long term sequelae in the form of lymphoproliferative disorders. ${ }^{1011}$ Ten $(26 \%)$ of 39 recipients in our series experienced primary EBV infection, which is less than the proportion reported by Breinig et al (24/42, $57 \%) .{ }^{15}$ Although the proportion of children who were EBV antibody positive was similar in both groups $(43 \% v 50 \%)$, reactivated EBV infection was not seen in our series but occurred in $48 \%$ of children in the Pittsburgh group. ${ }^{15}$

A variety of lymphoproliferative disorders, from transient non-malignant states to $B$ cell lymphoma, have been associated with EBV infection and also with cyclosporine treat- ment. ${ }^{3132} \mathrm{Ho}$ et al also established that the risk is increased with primary infection. ${ }^{10}$ Breinig $e t$ al described two children with lymphoproliferative disorders, developing two months and two years after primary EBV infection, one of whom developed an intestinal lymphoma. ${ }^{15}$ In our group, despite close follow up of the children at risk following EBV infection, no lymphoproliferative disorders were noted during nine months to four years of follow up.

Eighty per cent (eight of 10) of the children in our series who experienced primary infection were less than 3 years old. Hence this age group has a potentially increased risk of long term sequelae resulting from primary EBV infection.

Adenovirus infection causes a wide spectrum of illness in children. ${ }^{33}$ It has also been recognised as a cause of fulminant hepatitis and disseminated life threatening disease in immunocompromised hosts, including bone morrow, renal, ${ }^{34}$ and liver transplant recipients. ${ }^{10}$.

We found adenovirus infection in eight of 43 (19\%) recipients, which is comparable with the incidence reported by Koneru et al of 22/262 or $8.4 \%$ in a large study of adenovirus infection in paediatric liver transplant recipients. ${ }^{9}$ Their study relied on viral culture and isolation methods alone; we used chiefly serological evidence, with viral isolation and therefore typing in only two cases. Adenovirus types 1 and 2 accounted for $60 \%$ of isolates in Koneru's study and were responsible only for mild illness. All five patients who experienced adenovirus type 5 infection had severe fulminant hepatitis, all following treatment for rejection, and two patients died. Adenovirus type 7 was isolated only in one case and was associated with only mild disease. In our study the one child who had adenovirus type 7 infection had severe disseminated disease leading to fatal respiratory and hepatic failure.

Evidence of EBV infection in three cases, and CMV in one, was found simultaneously or within four weeks of adenovirus infection, suggesting an association between these infections in immunosuppressed patients. Such an association after organ transplantation has been documented. ${ }^{915}$

No specific treatment is available for adenovirus infection, although some therapeutic measures have been reported. ${ }^{35} 36$ We recently found in vitro evidence of a response to ganciclovir. ${ }^{36}$ Reduction of immunosuppressive treatment is essential and, to date, the only effective means of reducing morbidity.

Toxoplasma gondii has not been reported as a cause of morbidity in children who have undergone transplantation. In Cambridge the greatest incidence of $T$ gondii infection has been found in heart transplant recipients. ${ }^{712}$ Fifty seven per cent of those who were mismatched developed primary donor acquired infection, two of whom died of disseminated disease. One of two cases in the adult liver transplant series was also fatal. ${ }^{8}$ The child in our series who was infected with $T$ gondii was asymptomatic. The mild course of the infection may 
be explained by the concomitant reduction of immunosuppressive treatment and pyrimethamine.

In conclusion, this study confirms that CMV infection is the principal cause of serious viral disease in children after liver transplantation. EBV, adenovirus, and $T$ gondii infection also have the potential for producing serious disease. Surveillance for these infections and for long term sequelae should be included in the follow up of all children after transplantation. It is important to screen donors for CMV and $T$ gondii infection and to avoid donor/recipient mismatch whenever possible.

1 Ho $M$. Virus infections after transplantation in man: Brief review. Arch Virol 1977;55:1-24.

2 Zahradnik JM, Spencer MJ, Porter DD. Adenovirus infection in the immunocompromised patient. Am J Med tion in the imm

3 Ho M, Suwansirikul S, Dowling JN, Youngblood LA, Armstrong JA. The transplanted kidney as a source of cytomegalovirus infection. $N$ Engl J Med 1975;293: 1109-12

4 Fiala M, Payne JE, Berne TV, et al. Epidemiology of cytomegalovirus infection after transplantation and immunosuppression. J Infect Dis 1975;132:421-31.

5 Peterson PK, Balfour HH, Marker SC, Fryd DS, Howard RJ, Simmons RL. Cytomegalovirus disease in renal allograft recipients: A prospective study of the clinical features, risk factors and impact on renal transplantation. Medicine 1980;59:283-99.

6 Wreghitt TG, Hakim M, Gray JJ, et al. A detailed study of cytomegalovirus infections in the first 160 heart and heart/ lung transplant recipients at Papworth Hospital, Cambridge, England. Transplant Proc 1987;19:2495-6.

7 Hakim M, Wreghitt TG, English TAH, Stovin PGI, CoryPearce R, Wallwork J. Significance of donor transmitted disease in cardiac transplantation. J Heart Transplant 1985;IV:302-6.

8 Wreghitt TG, Hughes M, Calne R. A retrospective study of viral and Toxoplasma gondii infections in 54 liver transplant recipients in Cambridge Serodiagnosis and Immunotherapy 1987;1:219-39.

9 Koneru B, Jaffe R, Esquivel CO, et al. Adenoviral infections in paediatric liver transplant recipients. JAMA 1987; in paediatric

10 Ho M, Miller G, Atchison RW, et al. Epstein-Barr virus infections and DNA hybridization studies in post-transplantation lymphoma and lymphoproliferative lesions: The role of primary infection. J Infect Dis 1985;152 876-86.

11 Hanto DW, Gajl-Peczalska KJ, Frizzera G, et al. EpsteinBarr virus induced polyclonal and monoclonal B-cell lymphoproliferative diseases occurring after renal transplantation. Ann Surg 1983;198:356-62

12 Wreghitt TG, Hakim M, Cory-Pearce R, English TAH, Wallwork J. The impact of donor-transmitted CMV and Toxoplasma gondii disease in cardiac transplantation. Transplant Proc 1986;18:1375-6.

13 Wreghitt TG. Viral and Toxoplasma gondii infections. In Calne RY ed. Liver transplantation. 2nd ed. New York: Grune and Stratton, 1987:365-84.

14 Mejia G, Leiderman E, Builes M. Transmission of toxoplasmosis by renal transplant. Am J Kidney Dis 1983;11 615-7.

15 Breinig MK, Zitelli B, Starzl TE, Ho M, Epstein-Barr virus, cytomegalovirus and other viral infections in children after liver transplantation. $J$ Infect Dis 1987;156:273-9.

16 Bradstreet CMP, Taylor CED. Technique of complement fixation test applicable to the diagnosis of virus diseases. Monthly Bulletin of the Ministry of Health and Public Health Laboratory Service 1962;21:96-104.

17 Wreghitt TG, Hicks J, Gray JJ, O'Connor C. Development of a competitive enzyme-linked immunosorbent assay for detecting cytomegalovirus antibody. J Med Virol 1986;18:119-29.

18 Wreghitt TG, Gray JJ, Chandler C. The prognostic value of cytomegalovirus IgM antibody in transplant recipients. Lancet 1986;i:1157-8.

19 Henle G, Henle W. Immunofluorescence in cells derived from Burkitt's lymphoma. J Bacteriol 1966;91:1248-56.

20 Hinuma Y, Konn M, Yamaguchi J. Immunofluorescence and herpes type particles in the P3 HR-Burkitt lymphoma cell line. J Virol 1967;1:1045-51.

21 Gallo P, Walen KH, Riggs JL. Improved immunofluorescence antigens for detection of immunoglobulin $M$ antibodies to Epstein-Barr viral capsid antigen and antibodies to Epstein-Barr viral nuclear antigen. $J$ Clin Microbiol 1982;15:243-8.

22 Sairenji T, Sullivan JL, Humphreys RE. Complementdependent Epstein-Barr virus-neutralizing antibody appearing early in the sera of patients with infectious appearing early in the sera of patients with

23 Henle W Henle G, Zajac BA, Pearson G, Waubke R, Scriba $M$. Differential reactivity of human serums with early antigens induced by Epstein-Barr virus. Science 1970;169:188-90.

24 Balfour AH, Fleck DG, Hughes HPA, Sharp D. Comparative study of three tests (dye test, indirect haemagglutination test, latex agglutination test) for the detection of antibodies to Toxoplasma gondii in human sera. J Clin Pathol 1982;35:228-32.

25 Payne RA, Isaac M, Francis JM. Enzyme-linked immunosorbent assay (ELISA) using antibody class capture for the detection of anti-toxoplasma IgM. J Clin Pathol 1982;35:892-6.

26 Dummer JS, Hardy A, Poorsattar A, Ho M. Early infections in kidney heart and liver transplant recipients on cyclosporine. Transplantation 1983;36:259-67.

27 Peckham CS, Johnson C, Ades A. Early acquisition of cytomegalovirus infection. Arch Dis Child 1987;62:780-5.

28 Stern $\mathrm{H}$. Isolation of cytomegalovirus and clinical manifestations of infection at different ages $B r M e d J 1968$;i:665-9.

29 Betts RF. Cytomegalovirus infection in transplant patients. Prog Med Virol 1982;28:44-64.

30 Gray JJ, Alvey BA, Smith DJ, Wreghitt TG. Evaluation of a commercial latex agglutination test for detecting a commercial late aggerus in plant recipients. J Virol Methods 1987;16:13-19.

31 Nagington J, Gray J. Cyclosporin A immunosuppression, Epstein-Barr antibody and lymphoma. Lancet 1980;i: 536-7.

32 Starzl TE, Nalesnik MA, Porter KA, et al. Reversibility of lymphomas and lymphoproliferative lesions developing under cyclosporin-steroid therapy. Lancet 1984;1:583-7.

33 Brandt $\mathrm{CD}$, Kim $\mathrm{HW}$, Vargosco AJ, et al. Infections in 18,000 infants and children in a controlled study of respiratory tract disease: Adenovirus pathogenicity in relation to serological type and illness syndrome. $\mathrm{Am} \mathrm{J}$ Epidemiol 1969;90:484-500.

34 Stalder $\mathrm{H}$, Hierholzer JC, Oxman MN. New human adenovirus (candidate adenovirus type 35) causing fatal disseminated infection in a renal transplant recipient. $J$ Clin Microbiol 1977;6:257-65.

35 Dagan R, Swartz RH, Insel RA, Menegus MA. Severe diffuse adenovirus 7 a pneumonia in a child with combined immunodeficiency: possible therapeutic effect of human serum globulin containing a specific neutralizing antibody. Paediatr Infect Dis J 1984;3:246-51.

36 Wreghitt TG, Taylor DL, Gray JJ, et al. Disseminated adenovirus infection after liver transplantation and its possible treatment with ganciclovir. J Infect 1989;19: 88-91. 